\title{
Inovasi pada Organisasi Pemerintah: Tahapan dan Dinamika
}

\author{
Ridlowi $^{1}$ E Fathul Himam ${ }^{2}$ \\ ${ }^{1,2}$ Fakultas Psikologi Universitas Gadjah Mada
}

\begin{abstract}
Innovation has been identical with the use of new ways to gain the effectiveness and efficiency of a product, service, or methodology by a profit organization in order to face the business competition. The aim of this research is to see the dynamics that happen on innovation process run by government organization by taking case study on Computer Assisted Test (CAT) based employee selection system in National Civil Service Agency. The data are gathered through deep-interview to five research respondents by using qualitative approach. The results show that there are three main dimensions in the development proses of CAT system innovation: building the base of organization knowledge, designing innovation system, and developing system of continuity. The dimension of developing continuity system has become the unique characteristic in this study in comparison with the other results in regard to the process and innovation steps. Innovation in CAT system is a self-actualization of government organization to acquire and maintain its programs and authorities.
\end{abstract}

Keywords: authority, entities relationship, government organization, innovation

\begin{abstract}
Abstrak. Inovasi sering didentikkan dengan penggunaan cara baru oleh organisasi profit untuk memperoleh efektivitas dan efisiensi baik produk, pelayanan, maupun metode dalam menghadapi persaingan bisnis. Penelitian ini bertujuan untuk melihat dinamika yang terjadi pada proses inovasi yang dijalankan oleh organisasi pemerintah dengan mengambil studi kasus pada sistem seleksi pegawai berbasis Computer Assisted Test (CAT) Badan Kepegawaian Negara. Data diperoleh melalui wawancara mendalam terhadap lima orang narasumber penelitian dengan menggunakan pendekatan kualitatif. Hasil penelitian menunjukkan bahwa terdapat tiga dimensi utama proses pengembangan inovasi sistem CAT yaitu: membangun basis pengetahuan organisasi, merancang sistem inovasi, dan membangun keberlanjutan sistem. Dimensi membangun keberlanjutan sistem menjadi ciri khas dalam penelitian ini jika dibandingkan dengan temuan lain mengenai proses dan tahapan inovasi. Inovasi sistem CAT merupakan bentuk aktualisasi diri organisasi pemerintah untuk memperoleh serta mempertahankan otoritasi kewenangan dan program.
\end{abstract}

Kata kunci: hubungan kelembagaan, inovasi, kewenangan, organisasi pemerintah

Aksi inovasi yang dilakukan oleh organi-sasi pemerintah seolah menggejala. Hal ini ditandai dengan maraknya program dan layanan unggulan yang dija-

${ }^{1}$ Korespondensi mengenai isi artikel ini dapat dilakukan melalui: ridlowi@mail.ugm.ac.id

2 Atau melalui fathulhimam@yahoo.com jalankan pemerintah baik yang bersifat fisik maupun kebijakan. Seiring berjalannya waktu, realita menunjukkan organisasi pemerintah mulai bergerak lebih fleksibel dan mengikuti perubahan yang terjadi di lingkungan. Organisasi pemerintah mencoba keluar dari kekangan efek negatif dari 
birokrasi dengan mencoba lebih responsif terhadap perubahan dan tuntutan lingkungan. Hal ini menandai kondisi baru pada organisasi pemerintah yang disebut sebagai era post-bureaucracy (McKenna, Garcia \& Bridgman, 2010) maupun reburaeucratization (Harris, 2006). Kedua pendekatan menyuguhkan skema manajemen baru yang hybrid, fleksibel, tanggung jawab lebih didasarkan pada merit daripada hanya hierarki, pegawai diperlakukan sebagai individu yang dihargai hak pribadinya dan batas-batas organisasi men-jadi lebih terbuka. Dalam kajian organisasi, Mintzberg (1980) membagi desain organisasi ke dalam lima jenis yang berbeda yaitu: simple structure, machine bureaucracy, professional bureaucracy, divisionalized form, dan adhocracy. Dari kelima jenis desain ter-sebut, dua bentuk desain mencerminkan dinamika proses yang dijalankan organisasi pemerintah yakni machine bureaucracy dan professional bureaucracy. Machine bureaucracy menjalankan organisasi dengan proses kerja yang terstandar layaknya mesin, sangat formal dengan penggunaan spesialisasi kerja. Pengambilan keputusan bersifat terpusat dengan struktur menggunakan banyak level komando, pola komunikasi bersifat formal.

Di lain pihak, organisasi juga dapat bersifat birokratik tanpa harus mengedepankan karakter sentralisasi. Organisasi tetap bersifat birokratik dengan mengupayakan standarisasi perilaku (skill) melalui mekanisme koordinasi yang mendukung desentralisasi. Bentuk desain ini dikenal sebagai professional bureaucracy, organisasi memberdayakan sumber daya pegawai yang terlatih dan spesialis sebagai seorang profesional yang menjalankan bisnis utama dengan pemberian otonomi pelaksanaan tugas.

Perubahan merupakan hal yang tidak terelakkan di tengah perkembangan lingkungan organisasi baik internal maupun eksternal. Satu-satunya cara yang dapat ditempuh organisasi adalah dengan melakukan inovasi. Rogers (1983) mendefisisikan inovasi sebagai suatu ide, gagasan, praktek atau objek atau benda yang disadari dan diterima sebagai suatu hal yang baru oleh seseorang atau kelompok untuk diadopsi. Menurut Damanpour dan Gopalakrishnan (1998) inovasi merupakan ide atau perilaku yang memberikan hal baru bagi organisasi. Sementara Dasgupta dan Gupta (2009) memahami inovasi sebagai kesuksesan dalam memperkenalkan hal baru yang memiliki nilai guna seperti metode, teknik, praktek, produk atau pelayanan baru. Inovasi juga dilihat sebagai proses memikirkan dan mengimplementasikan hasil pemikiran sehingga menghasilkan hal baru berbentuk produk, jasa, proses bisnis, cara baru, kebijakan, dan sebagainya (Ancok, 2012). Osborne dan Brown (2005) melihat inovasi hanya terjadi ketika tercipta suatu produk atau pelayanan baru yang sebelum-nya belum ada sehingga muncul kondisi ketidakbersambungan (discontinuity) dengan produk sebelumnya. Isu discontinuity merupakan indikator dalam melihat suatu proses apakah dapat dikategorikan sebagai proses ino-vasi ataukah hanya perubahan semata.

Osborne dan Brown (2005) menyederhanakan proses inovasi dalam tiga tahapan utama yaitu invention stage, implementation stage, dan diffusion stage. Ancok (2012) menyederhanakan proses inovasi dalam tiga langkah utama yaitu: memproduksi gagasan, mengevaluasi gagasan, dan mengimplementasikan gagasan. Secara garis besar tahapan inovasi dirumuskan dalam tiga tahapan utama, yaitu proses inisiasi, adopsi, dan implementasi (Damanpour \& Schneider, 2006).

Untuk mendukung proses inovasi secara strategis, terdapat empat pendekatan perubahan yang dapat dilakukan organisasi (Daft, 2013). Empat pendekatan tersebut yaitu perubahan teknologi, perubahan produk dan pelayanan, perubahan struktur 
dan strategi, serta perubahan budaya Ancok (2012) melihat strategi yang dapat digunakan organisasi dalam melakukan inovasi diantaranya inovasi proses, inovasi metode, inovasi struktur organisasi, inovasi dalam pola hubungan atau interaksi, inovasi strategi, inovasi pola pikir, inovasi produk, serta inovasi pelayanan. Sementara Windrum (2008) memberikan taksonomi inovasi organisasi pemerintah yaitu inovasi pelayanan, inovasi administratif, inovasi pengembangan pandangan baru, inovasi kebijakan, serta inovasi sistemik yakni bagaimana memaksimalkan potensi jalinan kerja sama dengan organisasi luar.

Inovasi organisasi pemerintah merupakan proses dalam menciptakan, mengembangkan dan mengimplementasikan ide-ide baru yang dapat memberikan manfaat lebih baik seperti mengurangi biaya, meningkatkan efisiensi, dan efektivitas pelayanan (Nesta, 2014; Kobylinska \& Biglieri, 2015). Inovasi organisasi pemerintah didukung oleh munculnya era postbureaucracy yang mampu menggerakkan beberapa lini organisasi yang awalnya bersifat kaku. Era post-bureaucracy ditandai dengan peran hybrid yang dijalankan organisasi dengan karakteristik terbuka dan beragam dengan memberlakukan struktur organisasi baru yang lebih fleksibel. Post-bureaucracy melahirkan pola dan bentuk baru yang lebih "disagregrated", terjalin kerja sama dengan berbagai pihak termasuk pihak swasta (Harris, 2006). Dalam melihat bentuk jenis inovasi yang dilakukan organisasi pemerintah, Osborne mengklasifikasinya ke dalam empat jenis yang berbeda didasarkan pada tingkat pelayanan atau produk yang dapat diberikan dan tingkat kebutuhan yang diinginkan masyarakat. Keempat jenis inovasi tersebut yaitu: developmental change, expansionary innovation, evolutionary innovation, dan total innovation (Osborne \& Brown, 2005).

Developmental change merupakan bentuk paling dasar dari agenda peru- bahan yang terjadi pada level peningkatan pelayanan menggunakan pendekatan modifikasi cara sehingga tanpa melihat tingkat kebu-tuhan dari pelanggan. Osborne tidak menyebut jenis ini sebagai bentuk dari inovasi melainkan hanya perkembangan organisasi. Expansionary innovation dilakukan untuk memenuhi kebutuhan pelanggan dengan menggunakan bentuk pelayanan yang lama. Sebaliknya, evolutionary innovation melakukan inovasi atas dasar perubahan bentuk layanan tanpa melihat tingkat kebutuhan pelanggan. Sementara total innovation merupakan jenis pelayanan baru atas kombinasi dari pene-muan cara baru yang disesuaikan dengan tingkat kebutuhan pelanggan.

Salah satu faktor pendorong munculnya aksi inovasi pada organisasi pemerintah adalah adanya perubahan tuntutan peningkatan kualitas pelayanan dari lingkungan eksternal maupun stakeholder dan juga didorong oleh kebijakan yang diterapkan oleh pemerintah pusat melalui agenda program percepatan reformasi birokrasi. Salah satu agenda dari reformasi birokrasi ini dilakukan melalui program "inovasi pelayanan publik". Target yang hendak dicapai dari program ini adalah cita-cita pemerintahan kelas dunia (World Class Government) yang diharapkan dapat terwujud pada tahun 2025 (Imanuddin, 2016).

Dari tahun ke tahun, jumlah instansi yang berpartisipasi dalam kompetisi ini menunjukkan peningkatan. Pada tahun 2016, terdapat 2.476 inovasi peserta kompetisi untuk diseleksi menjadi Top 35 (Ramdhani, 2016). Padahal, pada tahun 2014 jumlah peserta yang mengikuti terdapat 515 peserta dan pada tahun 2015 sebanyak 1.188 peserta (KemenPAN-RB, 2015).

Salah satu contoh upaya implementasi inovasi oleh organisasi pemerintah dilakukan Badan Kepegawaian Negara (BKN) dalam mengelola proses seleksi pegawai berbasis Computer Assisted Test (CAT). Melalui CAT ini, BKN memperoleh 
penghargaan ASEAN Public Sector Organisation of the Year pada ajang Future Gov Awards se-Asia Pasifik di Kuala Lumpur Malaysia tahun 2014. Future Gov Awards merupakan ajang untuk menilai berbagai inovasi yang disajikan oleh sektor publik (BKN, 2014a).

CAT BKN dirancang untuk mengurangi, menghilangkan, atau mencegah terjadinya praktek Korupsi, Kolusi, dan Nepotisme (KKN) dalam proses seleksi pegawai. CAT menyuguhkan transparansi melalui skenario pelaksanaan seleksi berbasis komputer (BKN, 2014b).

Hal yang menarik dari proses inovasi ini adalah sistem CAT terlahir dalam lingkungan birokrasi yang secara prinsip memiliki perbedaan dengan budaya inovasi. Pada beberapa dekade, birokrasi terbukti sangat efektfif digunakan dalam menjalankan mekanisme kerja yang ketat dan teratur. Hal ini terkait dengan karakteristik struktur dan budaya yang cenderung statis, formal, rigid, memegang erat mekanisme status-quo dan tidak menyukai perubahan (Lembaga Administrasi Negara [LAN], 2014), kontradiktif dengan budaya inovasi yang menyukai fleksibilitas dan perubahan. Dalam menghadapi alih transfer teknologi informasi dan komunikasi, organisasi publik cenderung menunjukkan sikap yang lebih reaktif dibandingkan dengan organisasi swasta. Hal ini dipengaruhi oleh faktor birokrasi dan budaya yang dimiliki lembaga publik (Kamal, 2006).

Proses inovasi yang dijalankan organisasi pemerintah memiliki tingkat risiko yang beragam. Raipa dan Giedraityte (2014) memperlihatkan hambatan utama inovasi organisasi pemerintah terkait dengan kurangnya sumber daya pegawai potensial, kurangnya aturan yang mendukung iklim inovasi, kurangnya dukungan dari manajemen dan insentif bagi staf, ketidakpastian penerimaan dari pengguna layanan, hambatan budaya serta adanya resistensi dari pegawai. Borins (2001) mengungkapkan hambatan organisasi pemerintah dalam menjalankan proses inovasi terbagi dalam tiga kelompok utama yakni hambatan birokrasi, hambatan politik, dan hambatan lingkungan di luar organisasi.

Hasil kajian oleh LAN (2014) menunjukkan faktor-faktor penghambat inovasi organisasi pemerintah diantaranya: a) Ketergantungan yang tinggi kepada high performers yang seringnya menjadikan top leader sebagai sumber inovasi, b) Struktur kerja, budaya organisasi, serta proses birokrasi yang berbelit-belit meskipun teknologi tersedia, c) Tidak ada reward atau insentif untuk melakukan inovasi, d) Lemahnya kompetensi sumber daya pelaksana, e) Kurangnya dukungan anggaran, f) Tidak selarasnya tuntutan penyelenggaraan pelayanan publik dengan beban tugas administratif, g) Budaya status quo dan takut mengambil resiko.

Dengan melihat produk inovasi layanan CAT BKN, menjadi menarik untuk dilihat secara mendalam proses inovasi yang dilakukan di tengah tantangan budaya birokrasi dan hambatan yang ada di dalamnya. Bagaimana BKN sebagai organisasi pemerintah melakukan upaya pengembangan inovasi menjadi yang menarik untuk dikaji lebih dalam.

\section{Metode}

Penelitian ini merupakan penelitian kualitatif dengan pendekatan studi kasus untuk melihat dinamika yang dilakukan BKN dalam melakukan proses inovasi sistem CAT ditengah tantangan budaya birokrasi dan sumber daya yang dimiliki. Penelitian mengambil unit analisis sistem CAT sebagai tools proses seleksi penerimaan pegawai.

Proses penelitian dilakukan di Badan Kepegawaian Negara, salah satu lembaga pemerintah di Indonesia. Sumber data diperoleh melalui wawancara mendalam terhadap lima (5) orang narasumber yang 
dipilih berdasarkan kriteria yang ditetapkan (criterion sampling) yaitu: 1). Pegawai karir BKN dengan status Pegawai Negeri Sipil yang memiliki pengalaman, pengetahuan serta terlibat langsung dalam proses implementasi CAT BKN; 2). Bersedia menjadi narasumber dalam penelitian dengan menandatangani informed consent. Sementara penentuan narasumber diambil berdasarkan purposive sampling yakni peneliti memilih narasumber yang dianggap tepat untuk menjadi narasumber sesuai dengan kriteria. Narasumber penelitian dalam penelitian ini adalah: Kepala kantor, Kepala Bidang, dua (2) orang Kepala Seksi, serta Pejabat Fungsional Pranata Komputer. Pemilihan narasumber selain didasarkan pada faktor keterpenuhan kriteria, juga didasarkan pada aspek keterwakilan struktur dan pemangku jabatan karena dalam sistem birokrasi peran dari struktur kerja menjadi hal yang masih dominan.

Pelaksanaan penelitian dilakukan sesuai dengan tahapan berikut: 1). Pengurusan izin penelitian ke lembaga BKN tempat dilakukan penelitian; 2). Menghubungi calon narasumber untuk meminta kesediaan sebagai narasumber sekaligus bagian dari upaya building rapport; 3). Pengambilan data melalui wawancara mendalam yang diatur sesuai dengan kesepakatan waktu yang diperoleh dari para narasumber. Proses wawancara dilakukan secara bertahap, peneliti fokus pada satu narasumber sebelum berganti dengan narasumber lainnya mulai dari perencanaan waktu hingga selesai proses wawancara. Secara keseluruhan terdapat enam (6) kali proses wawancara terhadap lima (5) orang narasumber. Selama proses wawancara peneliti menggunakan alat bantu recorder untuk memudahkan dalam pendokumentasian data penelitian; 4). Mengolah data hasil wawancara, yakni mengolah bahan rekaman hasil wawancara menjadi verbatim; 5). Melakukan analisis dan interpretasi data secara induktif melalui kodifikasi data verbatim untuk diperoleh tema-tema spesifik, selanjutnya tema-tema spesifik tersebut dianalisis untuk diperoleh tema-tema yang lebih umum dan abstrak; 6). Melakukan member checking sebagai bagian dari kredibilitas penelitian untuk memastikan bahwa hasil penelitian yang dirumuskan peneliti telah sesuai dengan realitas peristiwa organisasi yang dialami nara-sumber; 7). Menyusun laporan penelitian.

\section{Hasil}

Setelah rangkaian proses analisis dan uji keabsahan data dilakukan, maka dapat disimpulkan bahwa terdapat tiga dimensi utama proses pengembangan sistem inovasi CAT yaitu: 1). Membangun basis pengetahuan organisasi, 2). Meran-cang sistem inovasi, dan 3). Membangun keberlanjutan sistem. Ketiga dimensi tersebut terangkum dalam tabel 1 .

\section{Hambatan teknis proses inovasi CAT}

Langkah awal sistem CAT untuk diterima sebagai program inovasi BKN tidak berlangsung mudah karena terkendala faktor kepercayaan bahkan di lingkungan internal BKN sendiri. Secara teknis, sistem pengelolaan CAT diatur secara terpusat mulai dari perencanaan, pelaksanaan, hingga pelaporan hasil.

Kebijakan terpusat pada satu sisi menjamin pelaksanaan sistem yang profesional akan tetapi secara tidak langsung juga menjadi penghambat proses pelaksanaan. Selain itu, keberadaan database soal tes yang tidak menjadi tanggung jawab BKN secara penuh menjadi hambatan tersendiri. Banyak permintaan fasilitasi tes yang tidak terakomodir karena ketidak-sediaan soal tes. Hambatan teknis lainnya terkait pelaksanaan tes seperti peserta gagal login, komputer hang, nilai tidak muncul, serta keberadaan joki tes. 
Hambatan sumber daya pengelola

Permasalahan umum yang dihadapi organi-sasi pemerintah adalah kondisi kurangnya sumber daya pegawai potensial. Meskipun secara kuantitas berjumlah besar, namun pada kenyataannya dirasakan sulit dalam mendukung kerja organisasi. Kesenjangan usia pegawai membawa implikasi pada kurangnya ketersediaan jumlah pegawai potensial sesuai kebutuhan tugas jabatan.

\section{Hambatan hubungan kelembagaan}

Belum jelasnya fungsi dan tugas kelembagaan antara satu lembaga dengan lembaga menjadi hambatan dalam pelaksanaan program. Perjalanan produk inovasi CAT tidak terlepas dari upaya tarik ulur kewenangan antar lembaga, antara BKN dengan lembaga lain. Hal ini terjadi mengingat setiap produk maupun kebijakan yang dilakukan BKN, juga merupakan produk dan kebijakan yang dapat memperoleh legitimasi dari lembaga lain. Terdapat tantangan antar lembaga berupa tarik ulur kewenangan serta adanya persaingan antar lembaga. Secara umum dinamika proses pengembangan inovasi sistem CAT terlihat pada bagan gambar 1 .

\section{Diskusi}

Hadirnya CAT merupakan paradigma baru dalam proses rekrutmen pegawai dalam bingkai sistem kerja birokrasi. Hal ini menunjukkan bahwa agenda inovasi telah masuk pada sistem kerja birokrasi peme-rintahan. Terdapat tiga pendekatan yang dilakukan organisasi pemerintah dalam menjalankan reformasi inovasi yaitu dengan melakukan perubahan dalam pengelolaan sumber daya manusia, penggunaan teknologi informasi dalam praktek kerja, serta kebijakan privatisasi (Maroto \& Rubalcaba, 2008). Penciptaan sistem CAT merupakan strategi perubahan cara dan mekanisme kerja berbasis pada penggu- naan teknologi informasi untuk meningkatan kualitas kerja.

Dalam perspektif jenis inovasi organisasi pemerintah, Osborne mengklasifikasinya kedalam empat jenis yang berbeda yakni developmental change, expansionary innovation, evolutionary innovation, dan total innovation (Osborne \& Brown, 2005). Bentuk inovasi sistem CAT lebih mendekati aksi total innovation yang merupakan penggunaan cara pelayanan baru disesuaikan dengan tingkat kebutuhan dari pelanggan. Sementara dalam kacamata strategi inovasi, terdapat dua pendekatan yang dapat dilakukan untuk menjalankan inovasi yaitu strategi inovasi proses dan inovasi pelayanan (Hilman \& Kaliappen, 2015). Jika dilihat dari kedua strategi, inovasi sistem CAT merupakan bagian dari inovasi proses karena mengetengahkan sebuah metode, cara, dan pengetahuan baru dalam menjalankan rekrutmen pegawai di Indonesia.

Melalui kedua pendekatan dapat dilihat bahwa proses inovasi sistem CAT merupakan bentuk dari total and process innovation karena mengetengahkan mekanisme baru sistem rekrutmen pegawai yang obyektif, transparan, dan akuntabel sebagai strategi dalam menjawab tantangan kebu-tuhan yang diharapkan oleh masyarakat. Hasil dalam penelitian ini menunjukkan bahwa proses pengembangan inovasi sistem CAT dilakukan melalui tiga langkah utama yaitu membangun basis pengetahuan organisasi, merancang sistem inovasi, dan membangun keberlanjutan sistem. Jika dibandingkan dengan penelitian lainnya, hal ini nampak berbeda dengan temuan Arpaci (2010) yang menunjukkan terdapat empat tahap utama dalam melakukan inovasi yaitu: penemuan ide, pengembangan pro-yek, produksi, dan inovasi. Sung, Cho, dan Choi (2011) juga memperlihatkan tiga tahapan utama proses inovasi yaitu: inisiasi, adopsi, implementasi 


\section{Tabel 1}

\section{Dimensi Pengembangan Inovasi Sistem CAT}

\begin{tabular}{|c|c|}
\hline Tema & Indikator Peri \\
\hline \multirow{4}{*}{$\begin{array}{l}\text { Membangun } \\
\text { Basis } \\
\text { Pengetahuan } \\
\text { Organisasi }\end{array}$} & Mengidentifika \\
\hline & pengetahuan \\
\hline & \\
\hline & Menyesuaikan \\
\hline & kebutuhan \\
\hline & stakeholder \\
\hline
\end{tabular}

Merancang

Sistem Inovasi

Melakukan
Kerjasama eksternal

1.

1. Mempelajari bahan atau sumber

2. Melakukan benchmarking

1. Merespon permasalahan didalam lingkungan organisasi

2. Merespon permasalahan yang berkembang diluar organisasi dalam proses rekrutmen

1. Melakukan kerjasama dengan perguruan tinggi dalam pengembangan database soal

2. Melakukan kerjasama dengan konsultan dalam pengembangan aplikasi dan instalasi

Merancang
mekanisme kerja

1. Mendesain operasionalisasi produk secara power full sepanjang waktu

2. Merancang sistem dengan tingkat keamanan dan kerahasiaan tinggi

3. Menyuguhkan fitur media yang dapat dilihat prosesnya secara terbuka

4. Kebijakan sentralisasi dalam pelaksanaan fasilitasi

5. Pelimpahan kegiatan dan kebijakan desentralisasi fasilitasi tes non CPNS

6. Sentralisasi kebijakan pada pananganan permasalahan

7. Mendesain jabatan fungsional pengelola bank soal

8. Menyiapkan infrastruktur pendukung

9. Pengelolaan sistem secara tim lintas bidang

10. Memilih sumber daya pengelola sesuai kualifikasi, potensi, dan kompetensi

11. Merekrut tenaga khusus pengelola soal

\begin{tabular}{|c|c|c|}
\hline & $\begin{array}{l}\text { 12. Melakukan pelatihan teknis bagi } \\
\text { sumber daya pengelola } \\
\text { 13. Melakukan skenario pemenuhan } \\
\text { kebutuhan SDM } \\
\text { 14. Pengayaan kompetensi bagi pegawai } \\
\text { yang memiliki potensi } \\
\text { 15. Melakukan pembinaan pegawai } \\
\text { 16. Mengambil langkah cepat, learning by } \\
\text { doing }\end{array}$ & $\begin{array}{l}\text { Sistem CAT dipercaya } \\
\text { sebagai media seleksi yang } \\
\text { obyektif, transparan, dan } \\
\text { akuntabel }\end{array}$ \\
\hline $\begin{array}{l}\text { Mengupayakan } \\
\text { legalitas produk }\end{array}$ & $\begin{array}{l}\text { 1. Melakukan skenario peraturan } \\
\text { 2. Melakukan simulasi untuk } \\
\text { memperlihatkan keunggulan produk } \\
\text { 3. Mempromosikan produk inovasi } \\
\text { 4. Memberikan dukungan kebijakan dan } \\
\text { teknis melalui pimpinan organisasi }\end{array}$ & $\begin{array}{l}\text { Digunakannya sistem CAT } \\
\text { sebagai media resmi proses } \\
\text { seleksi pegawai secara } \\
\text { nasional }\end{array}$ \\
\hline
\end{tabular}

\section{Sistem CAT dipercaya} sebagai media seleksi yang obyektif, transparan, dan akuntabel
Ide/gagasan dalam merancang program inovasi CAT Ide/gagasan alternatif solusi terhadap permasalahan rekrutmen pegawai Dimilikinya aplikasi CAT beserta database soal 
Lanjutan Tabel 1 Dimensi Pengembangan Inovasi Sistem CAT

\begin{tabular}{|c|c|c|c|}
\hline Tema & Indikator Perilaku & Contoh Perilaku & Hasil \\
\hline \multirow[t]{2}{*}{$\begin{array}{l}\text { Membangun } \\
\text { Keberlanjutan } \\
\text { Sistem }\end{array}$} & $\begin{array}{l}\text { Pengayaan fungsi } \\
\text { produk }\end{array}$ & $\begin{array}{l}\text { 1. Pengayaan fungsi CAT diluar tes seleksi } \\
\text { CPNS } \\
\text { 2. Pengayaan fungsi CAT dalam proses } \\
\text { manajemen kepegawaian }\end{array}$ & $\begin{array}{l}\text { Sistem CAT mampu eksis } \\
\text { ditengah konstalasi } \\
\text { lingkungan birokrasi }\end{array}$ \\
\hline & $\begin{array}{l}\text { Mempertahankan } \\
\text { domain kerja }\end{array}$ & $\begin{array}{l}\text { 1. Berpacu dalam inisiasi } \\
\text { program/kebijakan } \\
\text { 2. Bekerja dengan strategi tidak hanya } \\
\text { substansi } \\
\text { 3. Mencari celah peluang aktualisasi } \\
\text { 4. Mengoptimalkan peran dari sense of } \\
\text { belonging pegawai } \\
\text { 5. Melakukan branding terhadap produk } \\
\text { yang dihasilkan } \\
\text { 6. Menjadikan image positif organisasi } \\
\text { sebagai tujuan }\end{array}$ & $\begin{array}{l}\text { Otoritasi kebijakan dan } \\
\text { program }\end{array}$ \\
\hline
\end{tabular}

Ancok (2012) menyebutkan tiga langkah utama dalam proses inovasi yaitu: mem-produksi gagasan, mengevaluasi gagasan, dan mengimplementasikan gagasan. Dari beberapa pandangan tersebut memperlihatkan bahwa fase implementasi program menjadi bagi akhir dari agenda inovasi.

Dilain pihak, dari tahapan proses inovasi yang dijalankan CAT terlihat adanya perbedaan dengan beberapa proses inovasi lainnya khususnya dalam hal upaya membangun keberlanjutan sistem. Jika beberapa penelitian sebelumnya memperlihatkan tahapan proses inovasi berakhir pada eksekusi program, agenda inovasi sistem CAT tidak terhenti hanya pada tataran implementasi melainkan bagaimana produk inovasi yang dihasilkan mampu diakui dan tetap bertahan menjadi satu tahapan yang harus dijalankan. Apa yang berjalan pada sistem CAT cenderung mencerminkan pola tahapan utama proses inovasi yang digambarkan Rogers (1983).

Menurut Rogers, terdapat proses konfirmasi pada langkah inovasi sebagai bagian dari refleksi. Kondisi ini juga selaras dengan pandangan Zizlavsky (2013) yang menggambarkan proses inovasi diakhiri dengan melakukan refleksi. Demikian pula Osborne dan Brown (2005) menunjukkan proses evaluasi pelaksanaan inovasi sebagai tahap terakhir dalam skema model inovasi. Melalui beberapa argumentasi tersebut baik konfirmasi, refleksi, maupun evaluasi esensinya memiliki dimensi tahapan yang sama.

Dimensi membangun keberlanjutan sistem pada pengembangan sistem CAT identik dengan proses konfirmasi atau evaluasi karena didalamnya terdapat upaya melihat ulang keberadaan program inovasi yang sedang dijalankan. Kondisi demikian diperkuat dengan tujuan yang ditetapkan dalam sistem CAT yaitu bagaimana sistem CAT mampu eksis dalam bingkai dinamika lingkungan birokrasi dan konstalasi hubungan antar lembaga serta diperolehnya otoritasi program dan kebijakan. Hal ini mengindikasikan bahwa pada inovasi CAT secara tidak langsung telah terjadi pergeseran orientasi dari menyuguhkan sistem rekrutmen yang berkualitas kemudian berubah menjadi upaya membangun legitimasi dan otoritasi. Perubahan paradigma tersebut disebabkan oleh dinamika interaksi antar lembaga sebagai ciri yang tidak terpisahkan dari sistem birokrasi.

\section{Membangun basis pengetahuan organisasi}

Lahirnya ide inovasi CAT tidak terlepas dari proses pembelajaran organisasi (learning orientation) dari sumber pengetahuan yang 


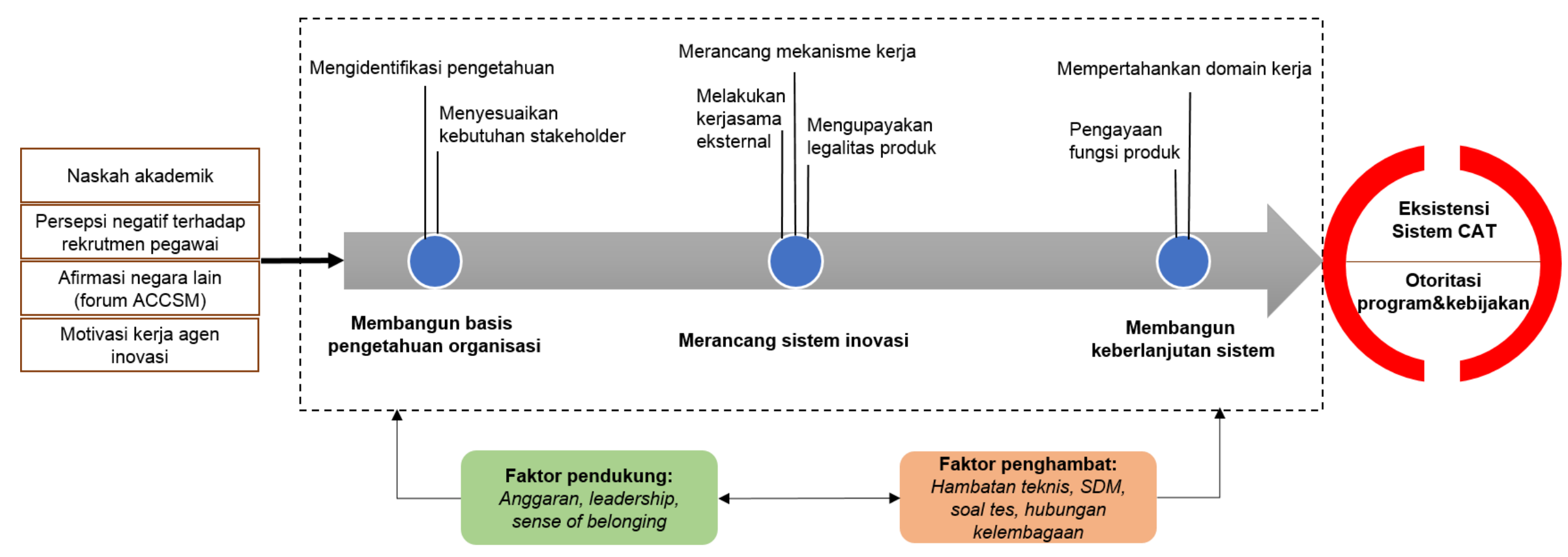

Gambar 1. Dinamika Pengembangan Inovasi Sistem CAT 
dimiliki BKN yakni dari naskah akademik, kegiatan benchmarking, dan permasalahan yang ada di lingkungan kerja. Naskah akademik digunakan sebagai bahan rumusan penyusunan peraturan perundang-undangan. Sementara benchmarking dilakukan melalui kunjungan kerja ke tempat rujukan pelaksanaan program yang hendak diwujudkan. Lacity dan Willcocks (2014) menunjukkan bahwa kegiatan benchmarking secara teknis mampu menjadi pendorong lahirnya agenda inovasi.

Pembelajaran organisasi sebagai basis dalam membangun pengetahuan tidak hanya dilakukan pada organisasi profit melainkan juga digunakan organisasi pemerintah untuk menyesuaikan tuntutan lingkungan eksternal dan juga pengembangan kapasitas sumber daya pegawai (Choi, 2012). Komitmen organisasi dalam melakukan pembelajaran akan mendorong terjadinya inovasi, learning orientation berkorelasi positif dengan terjadinya inovasi. Artinya, semakin proses pembelajaran didukung dan dilakukan maka akan memperkuat terjadinya inovasi.

Dalam perspektif pembelajaran organisasi, kegiatan mempelajari naskah akademik maupun benchmarking dapat dikategorikan ke dalam perspektif pemrosesan informasi yang menggunakan sumber daya organisasi untuk menambah dan meningkatkan kapasitas pengetahuan yang dimiliki (Dasgupta \& Gupta, 2009). Organisasi BKN melakukan identifikasi informasi yang relevan dan sesuai dengan latar belakang bidang pengetahuan yang dimiliki. Baik pengkajian naskah akademik maupun kegiatan benchmarking dapat menjadi sarana pembelajaran organisasi sebagai embrio awal dalam melakukan proses inovasi (Enz, 2012).

Selain mengidentifikasi pengetahu- an, upaya membangun basis pengetahuan organisasi juga dilakukan dengan cara menyesuaikan kebutuhan stakeholder (customer orientation). Hal ini terkait dengan permasalahan yang terjadi di lingkungan kerja khususnya dalam merespon tuntutan masyarakat terkait proses rekrutmen pegawai yang transparan dan berkualitas.

Permasalahan yang ada dalam pelaksanaan rekrutmen pegawai diidentikkan dengan aksi KKN sehingga mendorong para agen inovasi BKN mencari alternatif solusi. Seperti halnya learning orientation, customer orientation juga berkorelasi positif dengan terjadinya proses inovasi (Choi, 2012). Pada perspektif ini, pembelajaran organisasi dilihat sebagai upaya yang dilakukan organisasi untuk beradaptasi dengan perubahan akibat dari tuntutan yang ada di lingkungan eksternal (Dasgupta \& Gupta, 2009).

\section{Merancang sistem inovasi}

Sebagai langkah tindak lanjut dari penemuan ide inovasi sistem CAT, maka dilakukan langkah merancang sistem inovasi sebagai tahap pra implementasi program. Merancang sistem inovasi dilakukan melalui tiga skenario yakni melakukan kerja sama eksternal, merancang mekanisme kerja, dan mengupayakan legalitas produk. Kerja sama dengan pihak eksternal dilakukan dalam hal pengembangan soal untuk memenuhi database soal tes serta pengembangan aplikasi. Kerja sama dengan pihak eksternal merupakan pelaksanaan dari fase riset dan pengembangan dalam proses inovasi yang di dalamnya dibutuhkan sumber daya pengetahuan untuk menciptakan hal yang baru (Zizlavsky, 2013).

Kolaborasi antara pihak pemerintah dengan pihak eksternal sejatinya mampu meningkatkan kualitas dan efektivitas layanan yang diberikan organisasi pemerintah. Para agen inovasi dapat saling ber-tukar pengetahuan, pengalaman, dan kompetensi yang dimiliki (Cankar \& Petkovsek, 2013). Proses kolaborasi ini sejati-nya dapat dilihat juga sebagai perspektif pembelajaran bagi organisasi pemerintah (Kallio \& Lappalainen, 2015). Organisasi pemerintah 
telah menjadikan pihak eks-ternal sebagai bagian dari proses produksi inovasi, lebih terbuka dalam menerima masukan dan keterlibatan pihak luar (Sangiorgi, 2015). Hal ini menunjukkan bahwa pola open process innovation telah berlangsung pada organisasi pemerintah seperti BKN. Terdapat penggunaan pengetahuan lintas batas organisasi dalam melakukan inisiasi proses inovasi (Niehaves, 2010).

Selain melakukan kolaborasi dengan pihak eksternal, sistem inovasi dibangun melalui merancang mekanisme kerja. Mekanisme kerja disusun sebagai strategi teknis panduan dalam pelaksanaan inovasi agar agenda inovasi dapat dijalankan sesuai dengan standar operasional dan prosedur yang tepat. Mekanisme kerja juga disusun dalam rangka menggali keterlibatan seluruh sumber daya dan unit kerja yang ada sehingga keberadaan sistem CAT memperoleh dukungan bersama. Strategi partisipasi dari seluruh lini yang ada ter-bukti efektif dalam mendukung kesuksesan proses inovasi. Adanya proses konseling yang berfokus pada pegawai mendorong adanya partisipasi aktif pegawai dalam mensukseskan agenda inovasi (Enz, 2012).

Proses perancangan mekanisme kerja sistem CAT dalam prakteknya dapat dilihat sebagai penggabungan dari dua fase yang ada pada model proses inovasi yakni fase produksi dan fase implementasi (Zizlavsky, 2013). Kegiatan seperti merancang sistem dengan tingkat keamanan tinggi, sentralisasi kebijakan, mendesain jabatan fungsional pengelola soal, serta mendesain operasionalisasi produk sepanjang waktu merupakan strategi yang dilakukan pada fase produksi. Pada fase ini, segala asumsi dan preposisi diketengahkan untuk mempersiapkan segala kemungkinan yang dapat terjadi pada fase implementasi. Sementara kegiatan dalam merekrut tenaga potensial, pelatihan bagi pegawai pengelola, pengayaan kompetensi pegawai, pembinaan pega- wai, serta mengambil langkah cepat merupakan strategi yang menyertai pada pelaksanaan fase implementasi.

Merancang sistem inovasi pada prakteknya juga didukung dengan upaya memperoleh legalitas produk. Mengupayakan legalitas produk dilakukan untuk memberikan dukungan formal landasan hukum dari sistem CAT untuk menghindari kesalahan kebijakan. Melalui legalitas produk, operasionalisasi sistem CAT dapat dijalankan secara meyakinkan dengan adanya dukungan dari pemerintah. Sama halnya dengan inovasi organisasi pemerintah, aspek legalitas inovasi juga dibutuhkan pada organisasi bisnis untuk menghindari terjadinya penyalahgunaan proses imitasi maupun hak cipta produk. Aspek legalitas dapat dilihat pada saat proses inisiasi inovasi, proses pengembangan produk, maupun pelanggaran terhadap kesepakatan pasar (Banu, Dumitrescu, \& Purcarea, 2015).

Faktor kepemimpinan juga memberikan dukungan penting dalam mendukung legalitas produk. CAT dapat berjalan karena adanya kepemimpinan yang terbuka terhadap pembaruan, menerima masukan konstruktif serta berani dalam mengeksekusi program.

Aspek inovasi seringkali identik dengan pola pemimpinan transformasional yang terbukti memberikan pengaruh signifikan dalam menumbuhkan budaya inovasi organisasi yang berujung pada peningkatan kinerja superior (Sethibe \& Steyn, 2015). Transformational leadership merupakan implementasi dari gaya memengaruhi, menginspirasi, karisma, me-motivasi, serta menstimulan tumbuhnya pengetahuan sebagai modal tidak terhindarkan dalam menjalankan proses inovasi. Transformational leadership dapat mengubah paradigma berfikir pegawai untuk lebih tertarik berkontribusi kepada organisasi, bukan sebaliknya lebih banyak berharap dari organisasi (Hu, Gu, \& Chen, 2013). 


\section{Membangun keberlanjutan sistem}

Membangun keberlanjutan sistem dimaksudkan untuk menjamin eksistensi sistem CAT dapat terus berjalan di tengah konstalasi lingkungan birokrasi. Mem-bangun keberlanjutan sistem dilakukan untuk memperoleh otoritasi kebijakan dan program sebagai hal penting dalam setiap pelaksanaan kegiatan organisasi pemerintah. Upaya membangun keberlanjutan sistem CAT dilakukan melalui dua pendekatan yakni dengan melakukan pengayaan fungsi produk CAT, serta dengan upaya mempertahankan domain kerja. Lacity dan Willcocks (2014) menjelaskan salah satu hal terpenting dalam proses inovasi adalah bagaimana organisasi mampu menjaga keberlanjutan agenda inovasi lintas waktu. Hal ini dapat dilakukan melalui langkah akulturasi, inspirasi, pendanaan, serta injeksi. Untuk memperoleh keberlanjutan inovasi dibutuhkan langkah dalam menciptakan nilai-nilai tambah baik berupa produk baru dengan kinerja yang lebih unggul, biaya yang lebih rendah, maupun efisiensi proses yang lebih baik. (Metz, Burek, Hultgren, Kogan, \& Schwartz, 2016). Keberhasilan dan kegagalan inovasi pada ruang birokrasi bukan terletak pada kebaruannya namun pada tingkat pene-rimaan dan keberlanjutan inovasi. Hal ini dapat diwujudkan oleh pemimpin sebagai agen inovasi melalui otoritas kewenangan dan tingkat pemahaman yang dimiliki, kemauan dan keberanian menggunakan kewenangan, serta kreativitas (Widiyahseno, 2015).

Dalam implementasinya proses inovasi sistem CAT tidak terhindarkan dari faktor hambatan. Secara umum hambatan CAT berupa hambatan teknis, hambatan sumber daya pengelola, serta hambatan dalam konteks hubungan kelembagaan. Hambatan dalam sistem CAT ini selaras dengan Raipa dan Giedraityle (2014) yang memperlihatkan bahwa hambatan utama dari proses inovasi salah satunya terkait dengan kurangnya sumber daya pegawai potensial serta kurangnya aturan yang mendukung iklim inovasi. Borins (2001) juga mengungkapkan hambatan dalam menjalankan inovasi pada organisasi pemerintah terbagi dalam tiga kelompok utama yakni hambatan birokrasi, hambatan politik, serta hambatan lingkungan diluar organisasi.

Secara umum, hambatan pelaksanaan sistem CAT terkait dengan hambatan teknis maupun hambatan sumber daya pengelola dapat diatasi melalui strategi yang digunakan. Hal ini terbukti dari terlaksananya proses fasiltasi sistem CAT yang dapat terus berjalan hingga saat sekarang. Dilain pihak, hambatan terkait hubungan kelembagaan masih menjadi tantangan bagi sistem CAT. Beberapa kebijakan maupun desain ideal dari sistem CAT belum terwujud karena belum berhasilnya upaya harmonisasi tidak hanya dari internal BKN melainkan juga dari lembaga lain yang memiliki keterkaitan fungsi dan kewenangan.

Menghadapi tantangan hubungan kelembagaan tidak selalu identik dengan upaya konfrontasi dengan lembaga lain. Strategi ini harus dapat dilaksanakan secara tepat dengan tidak mendorong lahirnya situasi kompetisi yang berpengaruh pada pelaksanaan agenda inovasi berikutnya. Choi (2012) menunjukkan bahwa faktor kompetisi (competitor orientation) berkorelasi negatif terhadap proses inovasi yang dijalankan organisasi. Hal ini disebabkan karena faktor kolaborasi antar lembaga merupakan faktor penting pendorong kesuksesan (Kallio \& Lappalainen, 2015). Kolaborasi lebih mendorong terjadinya inovasi dibandingkan dengan kompetisi.

\section{Kesimpulan}

Penelitian ini menghasilkan beberapa temuan. Pertama, dapat disimpulkan bahwa organisasi BKN telah menjalankan proses inovasi melalui sistem Computer Assisted Test (CAT). Hal ini dibuktikan dengan hadirnya 
metode, cara, serta mekanisme baru dalam proses seleksi pegawai berbasis teknologi informasi. Kedua, penelitian ini memperlihatkan tiga dimensi utama dalam proses pengembangan sistem CAT yaitu: 1) membangun basis pengetahuan organisasi, 2) merancang sistem inovasi, dan 3) membangun keberlanjutan sistem. Secara karakter, inovasi sistem CAT termasuk dalam tipologi total $\mathcal{E}$ process innovation karena menghadirkan mekanisme dan proses baru sebagai jawaban terhadap tun-tutan masyarakat perihal proses rekrutmen yang transparan dan akuntabel.

Dimensi membangun keberlanjutan sistem menjadi ciri khas dalam penelitian ini jika dibandingkan dengan temuan-temuan sebelumnya tentang proses dan tahapan inovasi. Membangun keberlanjutan sistem muncul sebagai efek mekanisme hubungan kelembagaan, salah satunya dari belum jelasnya tugas pokok dan fungsi masingmasing lembaga yang memiliki irisan bidang tugas yang sama. Inovasi sistem CAT merupakan bentuk aktualisasi diri organisasi pemerintah untuk memperoleh maupun mempertahankan otoritasi kewe-nangan dan program.

\section{Saran}

Upaya yang telah dilakukan dalam membangun keberlanjutan sistem di antaranya dengan melakukan pengayaan fungsi CAT serta mempertahankan domain kerja. Pada konteks ini, upaya penetrasi BKN perlu didukung melalui penajaman branding BKN sebagai organisasi pengelolaan manajemen kepegawaian nasional. Untuk memperbesar peluang dalam membangun keberlanjutan sistem, dibutuhkan upaya yang lebih besar yakni strategi yang berefek pada penetrasi eksternal. Hal ini dapat dilakukan dengan cara memperbanyak inisiasi program maupun kebijakan sesuai dengan core business yang dimiliki. BKN perlu memperbanyak inisiasi program sebagai program unggulan maupun quick win, Selanjutnya, atas inisiasi program maupun kebijakan, perlu segera ditindaklanjuti dengan langkah branding.

Dalam mempertahankan keberlanjutan sistem, BKN juga diharapkan dapat menjalin komunikasi efektif dengan lembaga lain terlebih yang memiliki akses dalam mengambil kebijakan. Dibutuhkan kompetensi dan skill komunikasi efektif dengan didukung aktivitas-aktivitas non formal. Berkaca pada hasil tersebut, pemerintah didorong dapat melakukan kajian atau penataan ulang terkait dengan struktur, tugas pokok, maupun fungsi dari kedua lembaga pemerintah. Melalui kajian ulang diharapkan dapat dirumuskan secara lebih jelas pembagian tugas serta mekanisme kerja dari masing-masing lembaga sehingga tidak terjadi tumpang tindih kewenangan. Beberapa opsi langkah yang dapat dilakukan diantaranya upaya penggabu-ngan lembaga (merger) maupun aksi restrukturisasi pada masing-masing lembaga sehingga tidak terdapat dualism fungsi.

Penelitian ini melihat dinamika proses inovasi organisasi pemerintah dengan mengambil satu unit analisis, kedepan dapat dilakukan penelitian lanjutan dengan mengambil unit analisis yang lebih besar melibatkan beberapa organisasi pemerintah. Hal ini dapat meningkatkan peluang dalam proses generalisasi hasil sehingga kesimpulan yang dihasilkan mampu menggambarkan realitas sesungguhnya yang ada pada organisasi pemerintah di Indonesia. Selain itu, jika pada penelitian ini unit analisis yang diteliti berada pada level organisasi, maka dapat dilakukan eksplorasi lanjutan dengan mengambil unit analisis pada level individu pegawai. Bagaimana dinamika yang terjadi pada diri internal pegawai sebagai agen yang terlibat langsung dalam proses inovasi menyisakan celah dilakukan kajian. Hasil penelitian ini menunjukkan terdapat pola hubungan kelembagaan yang belum sepenuhnya sehat 
antara BKN dengan lembaga lain. Hal ini memberikan celah untuk dilakukan kajian mendalam mengeni dinamika dualisme peran yang dijalankan antar lembaga pemerintah.

\section{Kepustakaan}

Ancok, D. (2012). Psikologi kepemimpinan $\mathcal{E}$ inovasi. Jakarta: Erlangga.

Arpaci, I. (2010). E-government and technological innovation in Turkey. Transforming Government: People, Process and Policy, 4(1), 37-53.

Banu, G. S., Dumitrescu, A., \& Purcarea, A. A. (2015). The impact of imitation on innovation. FAIMA Business and Management Journal, 3(1), 15-28.

Badan Kepegawaian Negara (BKN). (2014a, Oktober 10). BKN raih penghargaan ASEAN Public Sector Organisation of The Year. Diunduh dari http://www.bkn.go.id/berita/bkn-raihpenghargaan-asean-public-sectororganisation-of-the-year tanggal 31 Agustus 2016.

Badan Kepegawaian Negara (BKN). (2014b). CAT BKN untuk Indonesia. Jakarta: Biro Humas dan Protokol BKN.

Borins, S. (2001). The challenge of innovating in government. Arlington: The Pricewaterhouse Coopers Endowment for The Business of Government.

Choi, S. (2012). Learning orientation and market orientation as catalysts for innovation in non-profit organizations. Nonprofit and Voluntary Sector Quarterly, 43(2), 393-413.

Daft, R. L. (2013). Organization theory $\mathcal{E}$ design (11 ${ }^{\text {th }}$ ed.). Mason: South-Western Cencage Learning.

Damanpour, F., \& Schneider, M. (2006). Phases of the adoption of innovation in organizations: Effects of environment organization and top managers. British Journal of Management, 17, 215-236.

Damanpour, F. \& Gopalakrishnan, S. (1998). Theories of organizational structure and innovation adoption: The role of environment change. Journal of Engineering and Technology Management, 15(1), 1-24.

Dasgupta, M. \& Gupta, R. K. (2009). Innovation in organizations: A review of the role of organizational learning and knowledge management. Global Business Review, 10(2), 203-224.

Enz, C. A. (2012). Strategies for the implementation of service innovation. Cornell Hospitality Quarterly, 53(3), 187195.

Harris, M. (2006). Technology, innovation and post-bureaucracy: The case of the british library. Journal of Organizational Change Management, 19(1), 80-92.

Hilman, H. \& Kaliappen, N. (2015). Innovation strategies and performance: are they truly linked?. World Journal of Entrepreneurship, Management and Sustainable Development, 11(1), 48-63.

Hu, H., Gu, Q., \& Chen, J. (2013). How and when does transformational leadership affect organizational creativity and innovation?. Nankai Business Review International, 4(2), 147-166.

Imanuddin, M. (2016, April 06). Inovasi pelayanan publik: percepatan peningkatan kualitas pelayanan publik. Kemepan-RB. Diunduh dari http://sinovik.menpan.go.id/index.php /site/article/223 tanggal 31 Agustus 2016.

Kallio, K. \& Lappalainen, I. (2015). Organizational learning in a innovation network: enhancing the agency of public service organization. Journal of Service Theory and Practice, 25(2), 140-161.

Kamal, M. M. (2006). IT innovation adoption in the government sector: Identifying 
the critical success factors. Journal of Enterprise Information Management, 19, 192-222.

Kobylinska, U., \& Biglieri, J. V. (2015). Public sector innovativeness in Poland and in Spain-comparative analysis. International Journal of Contemporary Management, 14(2), 7-22.

Lacity, M. \& Willcocks, L. (2014). Business process outsourcing and dynamic innovation. Strategic Outsourcing: An International Journal, 7(1), 66-92.

Lembaga Administrasi Negara (LAN). (2014). Inovasi di sektor publik. (Bahan Diklatpim III tidak diterbitkan). Jakarta: Lembaga Administrais Negara.

Maroto, A. \& Rubalcaba, L. (2008). Structure, size, and reform of the public sector in Europe. Dalam P. Windrum \& P. Koch (Ed.). Innovation in public sector services; entrepreneurship, creativity and management. Cheltenham: Edward Elgar.

McKenna, S., Garcia L. L., \& Bridgman, T. (2010). Managing, managerial control and managerial identity in the postbureaucratic world. Journal of Management Development, 29(2), 128136.

Metz, P., Burek, S., Hultgren, T. R., Kogan, S., \& Schwartz, L. (2016). The path to sustainability-driven innovation. Research-Technology Management, 50-60.

Mintzberg, H. (1980). Structure in 5's: a synthesis of the research on organization design. Management Science, 26(3), 322-341.

Nesta. (2014). Innovation in the public sector: how can public organisation better create, improve and adapt?. London: Nesta.

Niehaves, B. (2010). Open process innovation: the impact of personnel resource scarcity on the involvement of customers and consultants in public sector PBM. Business Process Management Journal, 16(3), 377-393.

Osborne, S. P. \& Brown, K. (2005). Managing change and innovation in public service organizations. Madison Ave, N.Y.: Routledge.

Raipa, A. \& Giedraityte, V. (2014). Innovation process barriers in public sector: a comparative analysis in Lithuania and the European Union. International Journal of Business and Management, 9(10), 10-20.

Ramdhani, J. (2016, Mei 26). Wapres JK serahkan penghargaan atas 35 inovasi pelayanan publik. Detiknews. Diunduh dari

https://news.detik.com/berita/3218950/ wapres-jk-serahkan-penghargaan-atas35-inovasi-pelayanan-publik tanggal 20 Juni 2017.

Rogers, E. M. (1983). Diffusion of Innovation ( $3^{\text {th }}$ ed.). Third Avenue, N.Y.: The Free Press.

Sangiorgi, D. (2015). Designing for public sector innovation in the UK: Design strategies for paradigm shifts. Foresight, 17(4), 332-348.

Sethibe, T., \& Steyn, R. (2015). The relationship between leadership styles, innovation and organisational performance: A systematic review. South African Journal of Economic and Management Sciences, 18(3), 325-337.

Sung, S. Y., Cho, D. S., \& Choi, J. N. (2011). Who Initiates and who implements? a multi-stage, multi-agent model of organizational innovation. Journal of Management \& Organization, 17, 344363.

Widiyahseno, B. (2015). Inovasi Bupati di ruang demokrasi: Meningkatkan tuntutan publik, mendorong kreasi birokrasi. Disertasi tidak diterbitkan, Pascasarjana Fisipol Universitas Gadjah Mada, Yogyakarta. 


\section{INOVASI ORGANISASI PEMERINTAH}

Windrum, P. (2008). Innovation and entrepreneurship in public services. Dalam P. Windrum \& P. Koch (Ed.). Innovation in public sector services; entrepreneurship, creativity and management. Cheltenham: Edward Elgar.

Zizlavsky, O. (2013). Past, present, and future of the innovation process. International Journal of Engineering Business Management, 5(47). 